\title{
Incidence of Nocardiosis among Patients with Lower Respiratory System infections
}

\author{
Enas A. Bady1, Kawther H.Mahdi2, Mohammed Y. Naji3 and Dheyaa B. AI-Rubeai 4 \\ 1College of Pharmacy, University of Basrah, Iraq \\ 2 College of Science, University of Basrah, Iraq \\ 3 College of Medicine, University of Basrah, Iraq \\ 4Director of respiratory and chest disease center, Basrah, Iraq
}

\begin{abstract}
A total of 93patients suffering from lower respiratory tract infections, including tuberculosis (44) and bronchitis (49) were recorded from December 2012 to February 2013. The patients ranged from 10 to 98 years of age and 57 male and 36female. Culturing of sputum samples onto Sabouraud dextrose agar was performed to the isolation of Nocardia. A total of 27 Nocardia genus were isolated from patients used in this study ; 5isolates were tuberculosis patients, 10 isolates were bronchitis patients, 5 isolates were tuberculosis and smoking patients, 1 isolate wase tuberculosis, smoking and diabetes mellitus patients, 2 isolates were bronchitis and diabetes mellitus patients and 4 isolates were bronchitis and smoking patients. The Nocardia isolates were showed the highest susceptibility against ofloxacin and ciprofloxacin and the lowest susceptibility against cefotaxime and erythromycin, but the isolates were resistant to oxacillin and rifampicin. Five isolates of Nocardia examined for susceptibility against eight hand sanitizer gels and eleven disinfectants. The results showed that the isolates of Nocardia were susceptibile against three hand sanitizer gels and nine disinfectants.
\end{abstract}

Keywords: Nocardia, respiratory tract infections, antibiotics, disinfectants, sanitizer gels. 


\section{INTRODUCTION}

Among the actinomycetes, members of the genus Nocardia are with the exception of mycobacteria, the most commonly implicated pathogens in human disease, mostly as opportunists (Beaman etal., 1995). Nocardia cause a variety of human infections including cutenous, pulmonary and systemic nocardiosis and most commonly presents as pulmonary disease (McNeil and Brown, 1994). Nocardia is a gram- positive aerobic bacteria and partially acid -fast (Chun and Goodfellow, 1995) and can formed filamentous branches that fragment into rod or coccid cells similar to fungal hyphae (Maza et al., 2004). Nocardia species is found world widely in the soil and water. Infections acquired by inhalation to the pulmonary routes or traumatic inoculation to the cutaneous routes in immunocompetent and immunocompromised patients (Forbes et al.,2007) such as patients with AIDS (McNeil and Brown,1994), elderly persons (Koneman et al.,1997), people on chronic steroid therapy, those with cancer, organ or bone marrow transplantation and HIV(Valenzuela-Tovar etal.,2005), diabetes mellitus and liver cirrhosis (Salh et al.,1988), sickle cell anemia(Sharma et al.,2007). Nocardia infection is called nocardiosis which may lead to secondary and fatal involvement with the brain, lung and meningitis alone or in combination with other organs and associated with a high mortality, especially when an appropriate antibiotic treatment is delayed (McNeil and Brown, 1994).Pulmonary tuberculosis mimics pulmonary nocardiosis both clinically and radio logically and many a time it is wrongly treated with antituberculosis drugs (Chopra et al., 2001).

Hospital and community-acquired infections constitute a serious public health problem all over the world (Hassan et al., 2012). Hospital acquired (nosocomial) infections are infections developing in hospitalized patients (Atul-Jain, 2007).
Community-acquired infections on the other hand are those acquired anywhere other than in a healthcare facility such as schools, exercise facilities, or any place where people come in contact with others or with surfaces that have been contaminated(Hassan et al., 2012). Hands are regarded as a major source of transmitting infection. It has been estimated that there are not less than 10000 organisms per $\mathrm{cm} 2$ of normal skin. This includes both nonpathogenic resident flora as well as pathogenic transient flora (Carter et al., 2000). More than 1.4 million people worldwide are suffering from infections acquired in hospitals. These nosocomial infections are also, in most cases, the result of poor hand hygiene. Thus, hand hygiene is a key component of good hygiene practices in the home and community and can produce significant benefits in terms of reducing the incidence of infection, most particularly gastrointestinal infections but also respiratory tract and skin infections (Bloomfield, 2007). Decontamination of hands can be carried out by washing hands with soap or by the use of hand sanitizer gels which may be either alcoholic (ethanol, isopropanol, and/or n-propanol are used) or non-alcoholic (benzalkonium chloride or the chlorinated aromatic compound triclosan or povidoneiodineaqueous) (Kumud et al., 2012).

Disinfectants are chemicals agents that destroy the growing forms of bacteria but do not destroy spore forms of microorganism. Disinfectants are applied on lifeless things resembling floor and work benches as phenols, chlorhexidine, hypochlorite and alcohol (Zuhlsdorf et al., 2004). The present investigation aimed to isolation of Nocardia from patients with respiratory infections and testing inhibition of Nocardia by antibiotics, hand sanitizer gels and disinfectants. 


\section{MATERIALS AND METHODS}

A total of 93 sputum samples were collected from patients with respiratory infections in the respiratory and chest disease center in Basra city from December 2012 to February 2013.The patients were included tuberculosis (44)and bronchitis (49), (13) were immunocompromised (with diabetes mellitus diseases) and (20 ) were smoking. The patients ranged from 10 to 98 years of age and 57 male and 36female. The clinical specimens from the sputum were inoculated onto Sabouraud dextrose agar for 3 weeks at $37^{\circ} \mathrm{C}$ (Singh et al., 1987).The antifungal agent cyclohexamide (actidione) at $50 \mu \mathrm{g} / \mathrm{ml}$ was added to the sterilized media at $46^{\circ} \mathrm{C}$ (Nazar et al.,1986) .Colonies were then stained with Gram staining and acid- fast staining by ZiehlNeelsen method (Benson,2002).Conventional and specific biochemical tests were used for the identification of Nocardia (Forbes et al., 2007).

The isolates were tested for their sensitivity to antibiotics by using the standard disc diffusion method (Bauer et al., 1966). A sterile cotton swab soaked in the bacterial suspension was used to inoculate the organisms onto the surface of Mueller-Hinton agar plates. The plates were incubated at $35^{\circ} \mathrm{C}$ for 48 hours. The resultant inhibition zone diameter for each disc was measured.

Seven types of alcohol hand sanitizer gels and ethanol 70\%( prepared at the moment of use by mixing $70 \mathrm{ml}$ absolute ethyl alcohol and $30 \mathrm{ml}$ distilled water) were used in this study purchased from local market and pharmacy as in table (1). The agar well diffusion assay as described by Kudi et al. (1999) was used to determine the inhibitory effect of various alcohol hand sanitizer gels and ethanol $70 \%$ on the bacterial growth. A sterile cork-borer (5 $\mathrm{mm}$ diameter) was used to make wells in the set agar. A McFarland 0.5 standardized bacterial suspension is swabbed over the surface of a Mueller- Hinton agar plate. $100 \mu$ of the alcohol hand sanitizer gels and ethanol $70 \%$ were added to each well and the plates were incubated overnight at $37^{\circ} \mathrm{C}$. Antibacterial activity was recorded if a zone of growth inhibition around the well is present (Mahon et al., 1998).

Table (1). Alcohol hand sanitizer gels used in the study and their ingredients.

\begin{tabular}{|c|c|c|c|}
\hline No. & Product & Ingredients & Industrial Co. \\
\hline 1 & FEAH & $\begin{array}{l}\text { Aqua, carbomer, ethanol, aminomethylpropanol, } \\
\text { isopropyl myristate, propylene glycol, vitamine E, } \\
\text { fragrance. }\end{array}$ & U.A.E. \\
\hline 2 & MARCH & Ethanol, glycerin,vitamine & Amman \\
\hline 3 & HYGEL & $62 \%$ ethanol, glycerin & U.A.E. \\
\hline 4 & $\begin{array}{l}\text { WORLD } \\
\text { WORKS }\end{array}$ & $62 \%$ ethanol & China \\
\hline 5 & HiGeen & $\begin{array}{c}\text { 70\% ethanol, glycerin, carbomer, Acrylate/c10-30 } \\
\text { akyl acrylate cross polymer, triethano- lamine, } \\
\text { hydroxyl propyl,methylcellulose, tocopheryl } \\
\text { acetate,cellulose,lactose. }\end{array}$ & Jordon \\
\hline 6 & Chicco & $\begin{array}{l}\text { Alcohol denat, copolymer, propylene glycol, } \\
\text { tetrahydroxy propyl, ethylenediamine. }\end{array}$ & Italy \\
\hline 7 & Clean & $75 \%$ ethanol,carbomer & Syria \\
\hline 8 & Ethanol 70\% & Ethanol 70\% & $\mathrm{BDH}$ \\
\hline
\end{tabular}


Eleven types of disinfectants were purchased from local pharmacy are used in this study as in table (2). The antibacterial activity was determined according to (Kudi et al. 1999 and Mahon et al., 1998). Results were analysed statistically by T-test.

Table (2). Disinfectants used in this study and their formulations and concentrations

\begin{tabular}{|c|l|c|c|c|}
\hline No. & \multicolumn{1}{|c|}{ Disinfectants } & Formulation & Industrial Co. & Conc. \\
\hline $\mathbf{1}$ & Poviofix & Povidone- iodine & Turkey & $10 \%$ \\
\hline $\mathbf{2}$ & Sarttol & $\begin{array}{c}\text { Dichloro-meta } \\
\text { Xylen,IPA,soap and pine oil }\end{array}$ & Jordon & - \\
\hline $\mathbf{3}$ & MTG & $\begin{array}{c}\text { Dichloro hexadine, IPA and } \\
\text { potassium chloride }\end{array}$ & Jordon & - \\
\hline $\mathbf{4}$ & Flash & $\begin{array}{c}\text { Dimethyle benzyl ammonium } \\
\text { chloride and hydrochloric acid }\end{array}$ & Turkey & $10 \%$ \\
\hline $\mathbf{5}$ & Happy & Hydrogen,peroxide, asyl cator & Turkey & - \\
\hline $\mathbf{6}$ & Formaldehyde & Formaldehyde & BDH & - \\
\hline $\mathbf{7}$ & $\mathbf{H}_{\mathbf{2}} \mathbf{O}_{2}$ & $\mathrm{H}_{2} \mathrm{O}_{2}$ & BDH & $3 \%$ \\
\hline $\mathbf{8}$ & Dettole & Chloroxylenol & Iraq & - \\
\hline $\mathbf{9}$ & SEHAT & Sodium hypochlorite & Iran & - \\
\hline $\mathbf{1 0}$ & ZODA & Sodium hypochlorite & Iran & - \\
\hline $\mathbf{1 1}$ & Isopropanol & Isopropanol & BDH & $\% 100$ \\
\hline
\end{tabular}

\section{RESULTS}

Among the 93sputum samples studied, a total of 27 nocardial isolates were detected from 25 sputum samples as 11 isolates from 10 samples of tuberculosis patients and 16 isolates from 15 samples of bronchitis patients (table3). Five isolates from 5 patients with tuberculosis only, 5 isolates from 4 patients with tuberculosis and smoking, lisolate from1patient with tuberculosis, smoking and diabetes mellitus, 10 isolates from 10 patients with bronchitis only, 2 isolates from 2 patients with bronchitis and diabetes mellitus and 4 isolates from 3 patients with bronchitis and smoking. Among of the 27 Nocardia isolates, 22 were detected in males and 5 in females (table 4).

Table (3): Clinical data of sputum samples.

\begin{tabular}{|l|c|c|c|c|}
\hline sputum samples & No. of samples & $\begin{array}{c}\text { No. of Nocardia positive } \\
\text { samples }\end{array}$ & $\begin{array}{c}\text { \% of positive } \\
\text { samples }\end{array}$ & $\begin{array}{c}\text { No. of } \text { Nocardia } \\
\text { isolates }\end{array}$ \\
\hline Tuberculosis & 44 & 10 & 22.73 & 11 \\
\hline Bronchitis & 49 & 15 & 30.61 & 16 \\
\hline Total & 93 & 25 & 26.9 & 27 \\
\hline
\end{tabular}


AL-Qadisiyah Journal of pure Science $\quad$ Vol.23 No.2 $\quad$ Year 2018

Table (4): Clinical data of positive Nocardia groups.

\begin{tabular}{|l|c|c|c|c|c|}
\hline \multicolumn{1}{|c|}{ Positive groups } & Age & Male & Female & Total No. & $\begin{array}{c}\text { No. of } \\
\text { Nocardia } \\
\text { isolates }\end{array}$ \\
\hline Tuberculosis & $30-48$ & 3 & 2 & 5 & 5 \\
\hline Tuberculosis and smoking & $36-55$ & 4 & - & 4 & 5 \\
\hline $\begin{array}{l}\text { Tuberculosis ,smoking and diabetes } \\
\text { mellitus }\end{array}$ & 24 & 1 & - & 1 & 1 \\
\hline Bronchitis & $12-98$ & 7 & 3 & 10 & 10 \\
\hline Bronchitis and diabetes mellitus & $31-45$ & 2 & - & 2 & 2 \\
\hline Bronchitis and smoking & $40-47$ & 3 & - & 3 & 4 \\
\hline Total & $12-98$ & 20 & 5 & 25 & 27 \\
\hline
\end{tabular}

The activity of 14 antibiotics against 14 isolates of Nocardia is presented in (table5). The sputum isolates of Nocardia were recorded significant differences, the highest susceptibility against ofloxacin and ciprofloxacin and the lowest susceptibility against cefotaxime and erythromycin. The susceptibility to other antimicrobial agents was variable; $50 \%$ of the isolates were susceptible to kanamycin, $36 \%$ to amikacin, penicillin and gentamycin, $29 \%$ to nalidixic acid and vancomycin, $21 \%$ to tobramycin and $14 \%$ to clindamycin. All the isolates were resistant to oxacillin and rifampicin. Twentynine per cent of the isolates showed intermediate susceptibility to erythromycin, $21 \%$ to nalidixicacid, $14 \%$ to clindamycin and rifampicin and $7 \%$ to gentamycin, tobramycin, amikacin and vancomycin.

Table (5): Susceptibility percentage of 14 Nocardia isolates against 14 antibiotics according to Benson (2002).

\begin{tabular}{|l|c|c|c|c|}
\hline \multicolumn{1}{|c|}{ Antbiotics } & Disk potency & \%Susceptible & \%Intermediate & \% Resistant \\
\hline Ofloxacin & $5 \mu \mathrm{g}$ & 57.1 & 0 & 42.8 \\
\hline Ciprofloxacin & $5 \mu \mathrm{g}$ & 57.1 & 0 & 42.8 \\
\hline Kanamycin & $30 \mu \mathrm{g}$ & 50 & 0 & 50 \\
\hline Amikacin & $30 \mu \mathrm{g}$ & 35.7 & 7.1 & 57.1 \\
\hline Penicillin & $10 \mathrm{U}$ & 35.7 & 0 & 64.2 \\
\hline Gentamycin & $10 \mu \mathrm{g}$ & 35.7 & 7.1 & 57.1 \\
\hline Nalidixic acid & $30 \mu \mathrm{g}$ & 28.5 & 21.4 & 50 \\
\hline Vancomycin & $30 \mu \mathrm{g}$ & 28.5 & 7.1 & 64.2 \\
\hline Tobramycin & $10 \mu \mathrm{g}$ & 21.4 & 7.1 & 71.4 \\
\hline Clindamycin & $2 \mu \mathrm{g}$ & 14.2 & 14.2 & 71.4 \\
\hline Cefotaxime & $30 \mu \mathrm{g}$ & 7.1 & 0 & 92.8 \\
\hline Erythromycin & $15 \mu \mathrm{g}$ & 7.1 & 28.5 & 64.2 \\
\hline Oxacillin & $1 \mu \mathrm{g}$ & 0 & 0 & 100 \\
\hline Rifampicin & $5 \mu \mathrm{g}$ & 0 & 14.2 & 85.7 \\
\hline
\end{tabular}




\section{AL-Qadisiyah Journal of pure Science $\quad$ Vol.23 No.2 $\quad$ Year 2018}

Table 6 below shows the significant differences of susceptibility pattern of 5 Nocardia isolates to the hand sanitizers in the agar diffusion test. All alcohol hand sanitizer gels tested showed no inhibitory effect against Nocardia isolates except FEAH gel , HiGeen gel and ethanol $70 \%$ against isolate (3) with inhibition zone $(15,12,13 \mathrm{~mm})$ respectively.

Table (6): Susceptibility pattern of 5 Nocardia isolates to alcohol hand sanitizer gels.

\begin{tabular}{|c|c|c|c|c|c|}
\hline Gel & $\begin{array}{c}N .(\mathbf{1}) \\
\mathbf{I Z}(\mathbf{m m})\end{array}$ & $\begin{array}{c}N .(\mathbf{2}) \\
\mathbf{I Z}(\mathbf{m m})\end{array}$ & $\begin{array}{c}N .(3) \\
\mathbf{I Z}(\mathbf{m m})\end{array}$ & $\begin{array}{c}N .(4) \\
\mathbf{I Z}(\mathbf{m m})\end{array}$ & $\begin{array}{c}N .(5) \\
\mathbf{I Z}(\mathbf{m m})\end{array}$ \\
\hline FEAH & - & - & 15 & - & - \\
\hline MARCH & - & - & - & - & - \\
\hline HYGEL & - & - & - & - & - \\
\hline WORLD WORKS & - & - & - & - & - \\
\hline HiGeen & - & - & 12 & - & - \\
\hline Chicco & - & - & - & - & - \\
\hline Clean & - & - & - & - & - \\
\hline Ethanol 70\% & - & - & 13 & - & - \\
\hline
\end{tabular}

- No inhibition

Table 7 below shows the significant differences of susceptibility pattern of 5 Nocardia isolates to the 11 disinfectants in the agar diffusion test. Flash and Formaldehyde were the only products that showed inhibitory activity against all the tested isolates with the highest activity $(66 \mathrm{~mm})$ and the lowest $(18$ $\mathrm{mm})$. Sarttol, MTG, $\mathrm{H}_{2} \mathrm{O}_{2}$ were active against some tested isolates and Happy, Dettole, Sehat and Isopropanol were active against one tested isolate. Poviofix and Zoda showed no activity against all the tested isolates.

Table (7): Susceptibility pattern of 5 Nocardia isolates to disinfectants

\begin{tabular}{|l|c|c|c|c|c|}
\hline \multicolumn{1}{|c|}{ Disinfectant } & $\begin{array}{c}\text { N.(1) } \\
\text { IZ(mm) }\end{array}$ & $\begin{array}{c}\text { N.(2) } \\
\text { IZ(mm) }\end{array}$ & $\begin{array}{c}\text { N.(3) } \\
\text { IZ(mm) }\end{array}$ & $\begin{array}{c}\text { N.(4) } \\
\text { IZ(mm) }\end{array}$ & $\begin{array}{c}\text { N.(5) } \\
\text { IZ(mm) }\end{array}$ \\
\hline Poviofix & - & - & - & - & - \\
\hline Sarttol & 13 & 15 & - & 17 & 20 \\
\hline MTG & 12 & 15 & - & 20 & 20 \\
\hline Flash & 18 & 24 & 27 & 30 & 20 \\
\hline Happy & 15 & - & - & - & - \\
\hline Formaldehyde & 57 & 66 & 52 & 66 & 55 \\
\hline H2O $_{2}$ & 15 & 25 & 25 & - & - \\
\hline Dettole & - & 20 & - & - & - \\
\hline SEHAT Bleaching & - & - & 35 & - & - \\
\hline ZODA Bleaching & - & - & - & - & - \\
\hline Isopropanol & - & - & 25 & - & - \\
\hline
\end{tabular}


AL-Qadisiyah Journal of pure Science $\quad$ Vol.23 No. $2 \quad$ Year 2018

-No inhibition
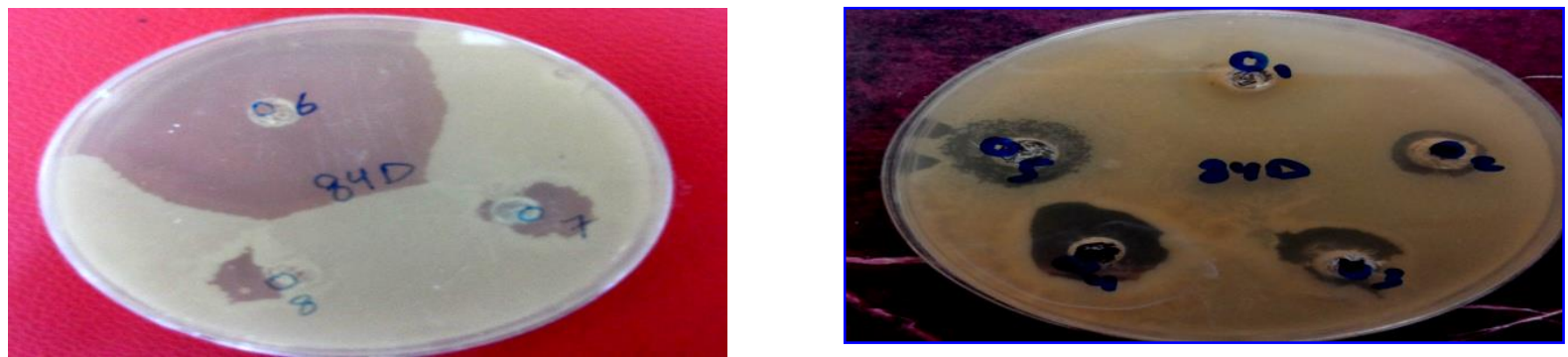

Nocardia 1
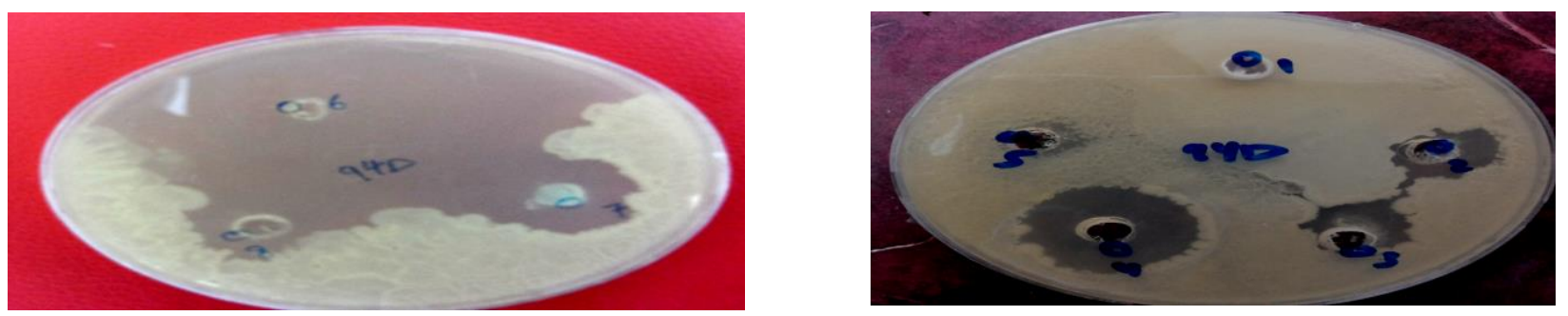

Nocardia 2
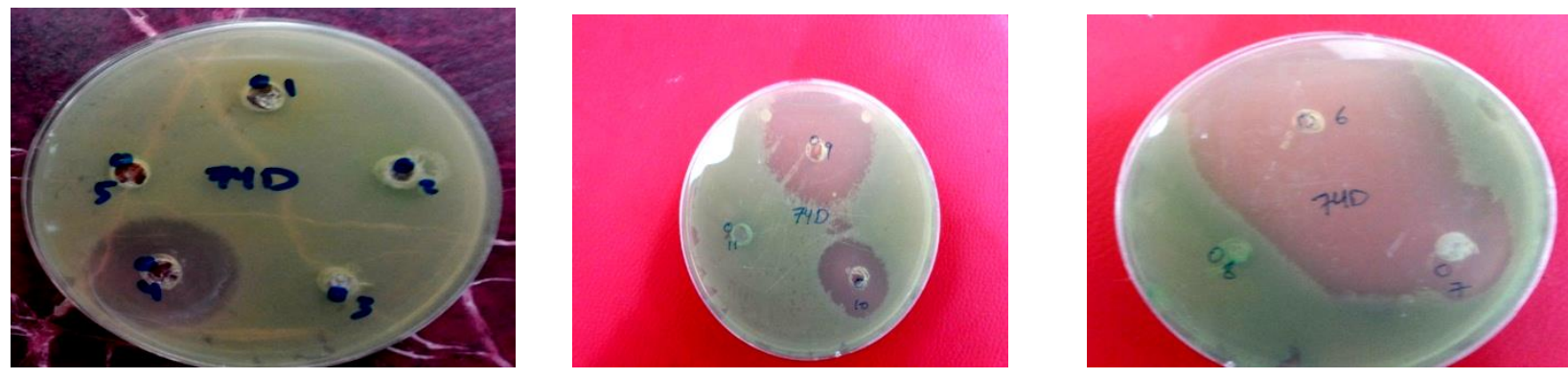

Nocardia 3
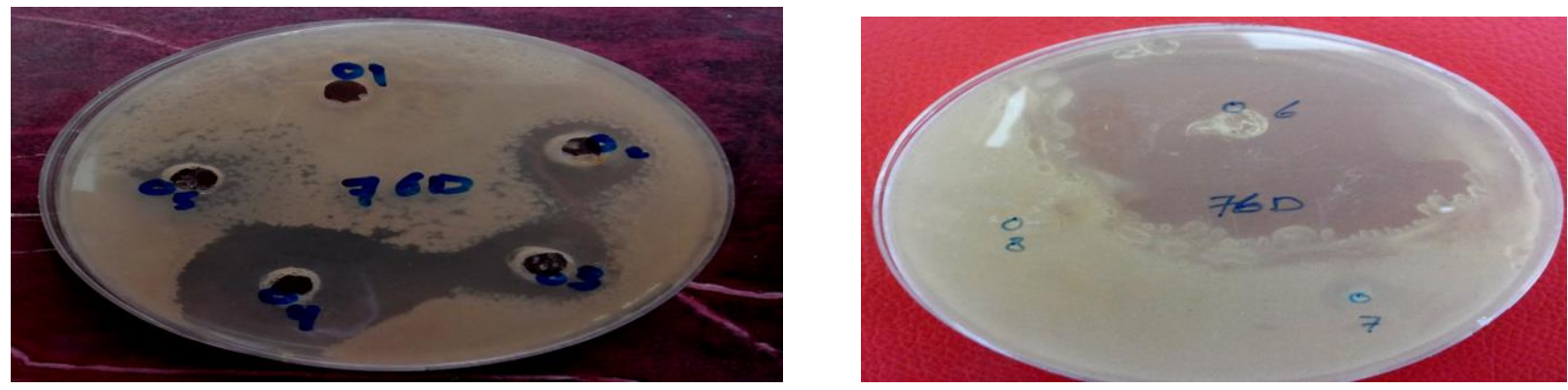

Nocardia 4 


\section{AL-Qadisiyah Journal of pure Science $\quad$ Vol.23 No. $2 \quad$ Year 2018}
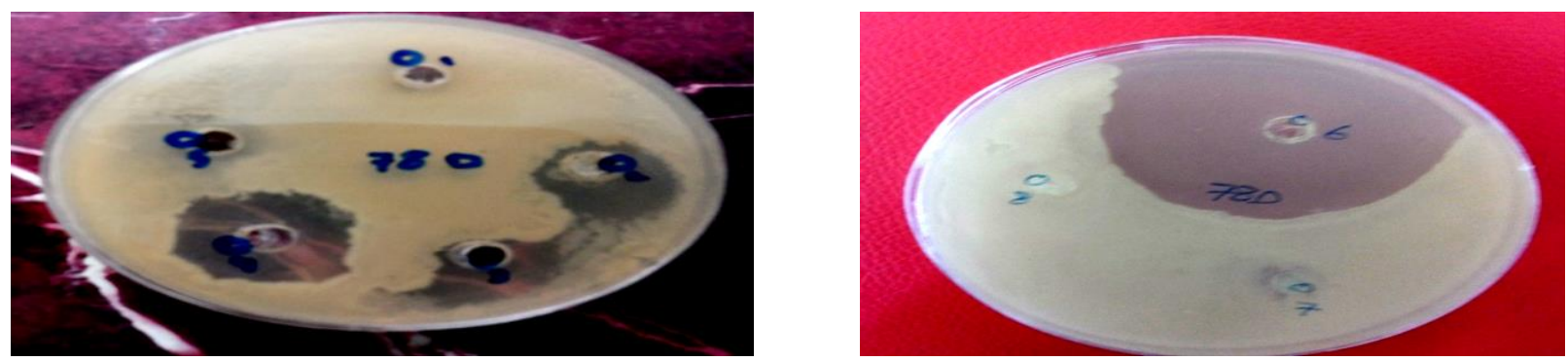

\section{Nocardia 5}

Figure (1): Inhibition zones diameter (mm) of Nocardia isolates against 11 disinfectants used in this study.

\section{DISCUSSION}

Nocardia belongs to the aerobic actinomycetes that are infrequently encountered in clinical practice but are considered medically important (Beaman \& Beaman, 1994 and McNeil and Brown, 1994). Manifestations and severity of infection caused by this group are extremely variable. Their clinical presentation is often nonspecific .Diagnosis is limited by the difficulty of isolation because of its slow growth and the need for invasive diagnostic procedures to obtain culture specimen (Lerner, 1996). The microorganism was first described by Nocard in 1888 as a fungus and was further classified as an aerobic bacteria that belongs to the genus Nocardia, order Actinomycetales. (Beaman and Sugar, 1983). Nocardiosis is a worldwide disease known as an infection that affects predominantly patients with immunodepressive diseases (Beaman \& Beaman, 1994).

The result of this study showed that the 27 Nocardia isolates were identified from a total of 93 sputum samples collected from patients with respiratory tract infections included 11 with tuberculosis and16 with bronchitis (table1). This result was in agreement with (El Hassan et al.,2010) who revealed that Nocardia considerable occurrence among patients with pulmonary infections giving clinical symptoms similar to those occur by M.tuberculosis infection,therefore,must be suspicion of pulmonary nocardiosis in immunocompromised patients, especially when the clinical and radiological picture mimics pulmonary tuberculosis but sputum is negative for AFB and patient is not responding to anti_tuberculosis drugs(Chopra et al., 2001). Among the 27 Nocardia isolates, 3 were detected from diabetes mellitus patients( immunocompromised), this result was agreed with previous study that reported case of pulmonary infection with Nocardia in Britain in woman suffered from diabetes mellitus and liver cirrhosis probably contributed to impaired cell mediated immunity(Salh et al.,1988).

Out of the 27 Nocardia isolates, 22were detected in males (7 with smoking) and 5 in females. Several investigators have reported that Nocardia infections were more frequently recognized in males than in females (Boiron et al. 1990 and Georghiou and Blacklock, 1992). This higher incidence of nocardiosis in males may be attributed to factors such as smoking, which was more frequently seen in males than in females in our area. The other factor may be that male and female sex hormones differently affect the growth or virulence of Nocardia (Hernandez-Hernandez et al., 1995).

Also, 27 Nocardia isolates in this study showed the highest susceptibility against quinolones such as ofloxacin and ciprofloxacin. Twenty-seven isolates in this 
study were resistant to oxacillin and rifampicin.The other antimicrobials showed the variable effects against 27 Nocardia isolates (table5).These results were in agreement with previous studies. ElHassan and El- Hamid(2005) were indicated that all Nocardia isolates which identified from pulmonary infections in Sudan were sensitive to ciprofloxacin, amikacin, clindamycin, gentamycin, Tobramycin and vancomycin, but resistance to oxacillin. Al-Habib and Abdulla (2008) and Larruskain et al. (2011) were concluded that amikacin one of the most important antimicrobials agents effective against Nocardia.Gomez-Flores etal. (2004) were observed that some antimicrobials such as amikacin, gentamicin and tobramycin have an effect on more than $66 \%$ of the Nocardia strains isolated from clinical specimens but they reported that quinolones such as ciprofloxacin and ofloxacin did not show any significant activity against the Nocardia isolates.

Hand hygiene is a means of making hands free of pathogens by using water with soap, hand rub or waterless sanitizers (Busari et al., 2012). Hand sanitizers are well-adapted to the skin ( Pedersen et al., 2005) and work by stripping away the outer layer of oil on the skin and also remove the cutaneous microflora (Axel et al., 2002). Ethanol has the record of being the oldest skin disinfectant; it acts as a permeation enhancer when applied topically to human skin. (Lachenmeier, 2008). Alcohol is used as the main antibacterial component of most waterless antiseptic agents due to its antimicrobial properties (Boyce and Pittet, 2002) and alcohol-hand sanitizer gel has significantly high efficacy in reducing transient micro flora on the hand (Verma et al., 2013).The antimicrobial activity of alcohols is based on its capacity to induce microbial protein denaturation. These were reported to have excellent and rapid germicidal activity against vegetative bacteria, fungi, and many viruses (Kumud et al., 2012).
The result of table 6 showed that all alcohol hand sanitizer gels used in this study no exhibited any inhibitory effect against Nocardia isolates except FEAH gel, HiGeen gel and ethanol $70 \%$ against Nocardia 3 isolate with inhibition zone $(15,12,13 \mathrm{~mm})$ respectively. Several studies suggested that, sanitizers with at least 70\% alcohol kill 99.9\% of the bacterial hands (Rotter, 1999) and effective against murine norovirus and feline calicivirus (Park et al., 2010). Alcohols cause damage to the cell membrane and rapid protein denaturation (McDonnell and Russell, 1999). However, previous studies showed that not all sanitizers are equally effective in eradicating all germs (Centers for Disease Control, 2003 and Garner and Favero, 1986). While some studies reported high efficacy of hand sanitizers in reducing the microbial flora of hand, other studies failed to show such efficacy of hand sanitizers (Blaney et al., 2011 and Liu et al., 2010).

Antiseptics and disinfectants are widely used in hospitals for various topical and hard surface applications. They play an essential role in the control of infection and prevention of nosocomial infections (Abadias et al., 2008 and Edgeworth, 2011). There is a wide variety of active ingredients to be found in different antiseptics and disinfectants (McDonnell and Russell, 1999). A variety of commercially available disinfectants are used by the public in their homes. In addition to commercially available products, several natural products also have been used by the public or for home health care (Chatburn et al., 1988). In recent years; concern for the environment has resulted in a movement to eliminate or replace antimicrobials such as disinfectants with environmentally safe or "green" alternative chemicals (Parnes, 1997). The results of table 7 showed that the disinfectants used in this study exhibited different activity against Nocardia isolates. Flash and formaldehyde were more effective followed by sarttol, MTG, $\mathrm{H}_{2} \mathrm{O}_{2}$ and happy, dettole, sehat, isopropanol respectively. Poviofix and zoda showed no activity against tested isolates. 
Formaldehyde as a highly effective, broad spectrum disinfectant, which typically achieve sterilization by denaturing proteins and disrupting nucleic acids (Ewart,2001) of fungi, viruses, mycobacteria, spores (Jeffrey,1995) and was found to be very effective in controlling the bacteria when compared with antibiotics (Sahul and Balasubramanian, 2000). Oxidizing agents are broad spectrum, peroxide based compounds that function by denaturing the proteins and lipids of microorganisms (Maris, 1995) and vary in their microbiocidal range, but are considered effective on hard surfaces and equipment (Grooms,2003). Hydrogen peroxide is considered as a bactericidal, virucidal (nonenveloped viruses may be resistant), fungicidal and at high concentrations sporicidal. Its activity against mycobacteria is limited (Jeffrey,1995). A published suggestion for treatment of jaw osteomyelitis caused by actinomycetes (Nocardia) includes surgical debridement of the lesion followed by surgical fistulation to allow lavage with sterile water, hydrogen peroxide and sodium hypochlorite (American Association of Zoo Veterinarians Infectious Disease Committee Manual 2013).

For many years iodine has been recognized as an effective broad- spectrum biocidal agent against bacteria, yeast and molds, Actinomycetes especially Nocardia and rickettsia (Jayaraja Kumar et al., 2009). Iodine, in the form of an aqueous or alcoholic solution, has been used as an antiseptic for 150 years. The precise mode of action of iodine is unknown. Iodine penetrates into the microorganisms and attacks certain groups of proteins, nucleotides and fatty acids. This leads to eventual cell death (McDonnell and Russell, 1999). Actenomyces israelii were highly susceptible to the antimicrobial action of sodium hypochlorite solution (Barnard et al., 1996), due to oxidative interaction with sulfydryl on certain enzymes that can be found in the cell membrane inhibited the cellular proteins' (Bodik et al., 2008) and affect bacterial DNA through the formation of chlorinated derivatives of nucleotide bases (McDonnell and Russell, 1999). A hypochlorite feed design option was chosen to inactivate and separate nocardioform bacteria within a concentrated scum manhole after aeration basin surface wasting ( Nicole et al., 2012). Some of the disinfectants did not inhibit the growth of the tested bacteria probably as a result of low concentrations or lack of biocides in them and or noncompliance to stringent condition (good manufacturing practices) during production among other reasons. Gross contamination of hand sanitizer during manufacturing may also compromise their effectiveness and or quality and possibly lead to infection of the users eventually (Voss and Widmer, 1997). Most species are susceptible sodium hypochlorite, formaldehyde, ethanol, propanol, hydrogen peroxide and iodine (Collins and Kennedy, 1999). Ethyl alcohol and isopropyl alcohol causes damage to the cell membrane and rapid protein denaturation. Many alcohol products include low levels of other biocides which remain after the alcohol has evaporated (McDonnell and Russell, 1999).

Some of the sanitizers examined did not inhibit the growth of the test bacteria probably as a result of low concentrations or lack of biocides in them and or noncompliance to stringent condition (good manufacturing practices) during production among other reasons. Gross contamination of hand sanitizer during manufacturing may also compromise their effectiveness and or quality and possibly lead to infection of the users eventually (Voss and Widmer, 1997). 
REFERRENCES

1-Al-Habib, H. M. and Abdulla, Z. A. (2008). A microbiological study of Nocardia, Legionella, and

Mycoplasma isolated from lower respiratory tract infections in iraqi patients. JIMA: 38486-

IMANA. Page 104(orginal article).

2-American Association of Zoo Veterinarians Infectious Disease Committee Manual 2013.

3-Atul-Jain, K. S. (2007). Recent advances in the management of nosocomial infections. JK Science,

9(1): 3-8.

4-Barnard, D. , Davies, J. and Figdor, D.(1996). Susceptibility of Actinomijces israelii to antibiotics,

sodium hypochiorite and calcium hydroxide. International Endodontic/oumal ., 29: 320-

326.

5-Bauer, A. W., Kinpy, W. N. and Turck, M. (1966). Antibiotic susceptibility testing by a standardization single discs, Amer. J. Clin. Pathol. 45: 493-496.

6-Beaman, B. L. and Suger, A. M. (1983).Nocardia in naturally aquired and experimental infections

in animals.J. Hyg. 91: 393-419.

7-Beaman, B. L. and Beaman, L.(1994). Nocardia species: host-parasite relationships. Clin.

Microbiol. Rev. 7(2): 213-264.

8-Beaman, B. L., Saubolle,M. A. and Wallace, J. (1995). Nocardia, Rhodococcus, Streptomyces,

Oerskovia, and other aerobic actinomycetes of medical importance, p. 379380. In Murray,
P.R., Baron, E. J., Pfaller, M. A., Tenover, F. C. and Yolken, R. H. Manual of clinical

microbiology, 6th ed. American Society for Microbiology, Washington, D.C.

9-Benson, H. J. (2002). Microbiological applications. Laboratory manual in general microbiology.

$8^{\text {th }}$ ed., The McGraw Hill companies, Inc. 1221 Avenue of the Americas, New York, NY

10020.

10-Blaney, D.D, Daly, E.R., Kirkland, K.B., Tongren, J.E., Kelso, P.T. and Talbot, E.A. (2011).

Control use of alcohol based hand sanitizers as a risk factor for norovirus outbreaks in long

term facilities in northern New England. Am. J. Infect. 39(4): 296-301.

11-Bloomfield, S. F. (2007). The Effectiveness of Hand Hygiene Procedures in Reducing The Risks

of Infections in Home and Community Settings Including Handwashing and Alcohol-Based

Hand Sanitizers", American Journal of Infection Control,35(10): S27-S64.

12-Boiron, P., Provost, F., Chevrier, G.and Dupont, B. (1992).Review of nocardial infections in

France 1987 to 1990. Eur. J. Clin. Microbiol. Inf. Dis., 11: 709-14.

13-Carter, S. J. (2000). Aseptic technique Cooper and Gunn's Dispensing for Pharmaceutical

Students, 12th Edition, CBS Publishers and Distributors : 494-540.

14-Centers for Disease Control (2003). Guideline for hand hygiene in health-care settings. Morbidity 

431-433.

and Mortality Weekly Report., 53:

15-Chatburn, R.L., Kallstrom, T.J. and Bajaksouzian, S. (1988). A comparison of acetic acid with a

quaternary ammonium compound for disinfection of hand-held nebulizers. Respir. Care. ,

$$
\text { 33:179- } 187 \text {. }
$$

16-Chopra, V., Ahir, G.C., Chand, G. and Jain, P. K. (2001). Pulmonary nocardiosis mimicking

pulmonary tuberculosis .Ind .J. Tub.,48(211): (211-213).

17-Chun, J. and Goodfellow, M. (1995). A phylogenetic analysis of the genus Nocardia with $16 \mathrm{~S}$

Bact. 45: 240-245.

rRNA genes sequences. Int. J. Syst.

18-Collins, C.H. and Kennedy, D. A. (1999). Laboratory acquired infections. History, incidence,

causes and prevention (4th ed): 1-37

Woburn, MA: BH.

19-Edgeworth, J.D. (2011). Has decolonization played a central role in the decline in UK

methicillin-resistant Staphylococcus

aureus transmission? A focus on evidence from

intensive care. J. Antimicrob. Chemother., 66 (2): 41-7.

20-El Hassan, M. M. and Hamid, M. E. (2005). In vitro antimicrobia sensitivity testing of Nocardia

africana strains recently isolated from patients with pulmonary infections in Sudan. Bahrain

Medical Bulletin, 27(1): 1-6.

21-El Hassan, M. M., Saeed, N. S., Hamid, M.

E. and Goodfellow, M. (2010). Pulmonary nocardiosis; similarity to tuberculosis (A bacteriological and proteomics Study). Egypt.

$$
\text { Acad. J. biolog. Sci., 2(2): } 15-25 .
$$

22-Ewart, S.L. (2001). Disinfectants and control of environmental contamination. In: Smith, B.L.

editor. Large Animal Internal Medicine: diseases of horses cattle, sheep and goats. 3rd ed.

St. Louis: Mosby:1371-1380.

23-Forbes, B. A.; Sahm, D. F. and Weissfeld, A. S. (2007). Bailey and Scott's diagnostic microbiology. $12^{\text {th }}$ ed. Mosby Elsevier.

24-Garner, F.S. and Favero, M.S. (1986). CDC guideline for hand washing and hospital infection control. Infect. Control., 231-235.

25-Georghiou, P.R. and Blacklock, Z.M.(1992). Infection with Nocardia species in Queensland: a

review of 102 clinical isolates. Med. J. Aust., 156:692-7.

26-Gomez-Flores, A., Welsh, O., SaidFernandez, S., Lozano-Garza, G., and Tavarez-Alejandro,

R.E. and Vera-Cabrera, L. (2004). In Vitro In Vivo Activities of Antimicrobials against

Nocardia brasiliensis .Antimicrob Agents Chemother. 48(3): 832-837.

27-Grooms, D. (2003). Biosecurity guide for livestock farm visits. Michigan State University

Extension Bulletin E2842.

28-Hassan, A. O., Hassan, R.O., Muhibi, M. A. and Adebimpe, W. O. (2012). A survey of 


\section{AL-Qadisiyah Journal of pure Science $\quad$ Vol.23 No. $2 \quad$ Year 2018}

Enterobacteriaceae in hospital and community acquired infections among adults in a tertiary

health institution in Southwestern Nigeria. Afr. J. Microbiol. Res., 6(24): 51625167.

29-Hernandez-Hernandez, F., Lopez-Martinez, R. and et al. (1995). Nocardia brasiliensis: in vitro

and in vivo growth response to steroid sex hormones. Mycopathologia 132 (2): 79-85.

30-Hernandes, S. E. D., Mello, A. C., Ana, J.J. S., Soares, V. S., Cassiolato,V., Garcia, L.B., Cardoso, C.L. (2004). The effectiveness of alcohol gel and other hand cleansing agents

against important nosocomial pathogens. Brazilian J. of Microbio., 35:33-39.

31-Jayaraja Kumar,K., Hemanth Kumar, R..C, Gunashakaran,V., Ramesh,Y., Kalayan Babu,P.,

Pawan Narasimha,N., Venkatewarulu,A. and Lakshmikanth Reddy,P.(2009). Application of broad spectrum antiseptic povidine iodine as powerful action: A review. J.of Pharma. Sci. and Techno. , 1(2): 48- 58.

32-Jeffrey, D.J. (1995).Chemicals used as disinfectants: Active ingredients and enhancing additives.

Rev. sci. tech. Off. int. Epiz.:14(1):5774.

33-Jessica Hilburn, M.T., Hammondb, B. S., Fendler, E. J. and Groziak, P.A. (2003). Use of alcohol

hand sanitizer as an infection control strategy in an acute care facility. Am. J. Infect. Control,

$$
\text { 31(2):109-1916. }
$$

34-Koneman, E.W., Allen, S.D., Janda, W.M. and Schreckenberger, Winn W.C.Jr. (1997) Color

atlas and textbook of diagnostic microbiology, 5th ed., Lippincott, Philadelphia, USA, 651708.

35-Kudi ,A., Umoh, J., Eduvie ,L. and Gefu,J. (1999). Screening of some Nigerian medicinal plants

$$
\text { for antibacterial activity. }
$$

Ethnopharmacol., 67: 225-228.

36-Kumud, M., Neha, P. and Seema, T.(2012). Comparative evaluation of efficiency of alcoholic

Vs non- alcoholic hand sanitizers. Int. J. Life Sc. Bt \& Pharm. Res.,1(4): 173177.

37-Larruskain, J., Idigoras, P., Marimón, J. M. and Pérez-Trallero, E.(2011). Susceptibility of 186

Nocardia sp. Isolates to 20 Antimicrobial Agents Antimicrob Agents Chemother. 55(6):

$$
\text { 2995-2998. }
$$

38-Lerner, P.I. (1996). Nocardiosis. Clin Inf. Dis., 22(6): 891-903.

39-Liu, P., Yuen, Y., Hsiao, H.M., Jaykus, L.A. and Moe, C. (2010). Effectiveness of liquid soap

and hand sanitizer against Norwalk virus on contaminated hands. Appl. Environ. Microbiol.

$$
\text { 76(2): 394-399. }
$$

40-Mahon, C., Smith, L. and Burns, C. (1998). An introduction to clinical laboratory sci. W.B.

$$
\text { Saunders Company.,:37-43. }
$$


41-Maris,P. (1995).Modes of action of disinfectants. Rev. sci. tech. Off. int. Epiz. :14(1):47-55.

42-Maza, L. M.; Pezzlo, M. T.; Shigei, J. T., Peterson, E. M. (2004). Colour atlas of medical bacteriology. ASM Press. Washington, USA.

43-McDonnell, G. and Russell, A.D. (1999). Antiseptic and disinfectants: activity, action and 12(1):147-179.

resistance. Clin. Microbiol. Rev.,

44-McNeil, M. M. and Brown, J. M. (1994). The medically important actinomycetes: epidemiology

and microbiology .Cited by Torres, R. D. C., Oletta, C. A. and Zlotnik, H. (1996). A rapid

and gentle method for isolation of genomic DNA from pathogenic Nocardia spp. Cli. and 3(5): 601-604.

Diagnostic Laboratory Immunology

45-Nazar, M., Jassim, M. Al-Hassan and Pridham, T. C. (1986). Thermodurant sandy desert soil

Streptomyces from plant rhizosphere exposed to natural gas. J. Univ. Kuwait, 13:220-225.

46-Nicole, D.A., Emily, D. and Kimberly, W.( 2012). A chlorination system for the scum manhole at

the Sturbridge wastewater treatment plant . A major qualifying project proposal of Worcester Polytechnic Institute.

47-Park, G.W., Barclay, L., Macinga, D., Charbonneau, D., Pettigrew, C. A. and Vinje, J. (2010).
Comparative efficacy of seven hand sanitizers against Murine Norovirus, Feline Calicivirus,

and GII.4 Norovirus3. J. of Food Protection, 73(12): 2232-2238.

48-Parnes, C.A. (1997).Efficacy of sodium hypochlorite bleach and"alternative" products in

preventing transfer of bacteria to and from inanimate surfaces J. Environ. Health., 59:14-20.

49-Rotter, M. (1999). Hand washing and disnfection. In: Mayhall CG, ed. Hospital epidemiology

and infection control. 2nd ed. Baltimore: Williams and Wilkins. 1339-55.

50-Sahul, H. A.S. and Balasubramanian, G.(2000). Antibiotic resistance in bacteria isolated from

Artemia nauplii and efficacy of formaldehyde to control bacterial load. Aquaculture 183:

195-205.

51-Salh, B., Fegan, C., Hussain, A., Jaulim, A., Whale, K. and Webb, A. (1988). Pulmonary

infection with Nocardia caviae in a patient with diabetes mellitus and liver cirrhosis. Thorax.

$$
\text { 43(11): 933-934. }
$$

52-Sharma, M., Gilbert, B. C., Benz, R. L. and Santoro, J. (2007). Disseminated Nocardia

Otitidiscaviarum infection in a woman with sickle cell anemia and end-stage renal disease.

The American J. of the Medical Sci. 333(6): 372-375.

53-Singh, M., Sandhu, R. S. and Randhawa, H. S. (1987). Comparison of paraffin baiting and 
conventional culture techniques for isolation of Nocardia asteroids from sputum. J. Clin.

Microbiol. 25(1): 176-177.

54-Valenzuela-Tovar, J.F., Contreras-Perez, C., Shibayama-Hernandez, H. ChavezGonzalez, L., et

al. (2005). Original article,

Biochemical identification and molecular characterization (PCR-RFLP) of Nocardia isolates from sputum. Arch. of Medi. Res., 36:356-361.

55-Verma, D.K., Tesfu, K., Getachew, M., Workineh, Y., Mekuriaw, F. and Tilahun, M.(2013).
Evaluation of antibacterial efficacy of different hand gel sanitizers in university of Gondar

students, north-west Ethiopia. J. of Global Biosci., 2(6): 166-173.

56-Voss, A. and Widmer, A.F.( 1997). No time for handwashing!? Hand washing versus alcoholic

rub: can we afford $100 \%$ compliance? Infect Control Hosp Epidemiol, 18(3):205208.

57-Zuhlsdorf, B., Floss, H. and Matiny, H. (2004). Efficacy of 10 different cleaning processes in a

washer-disinfector for flexible endospores. J. Hosp. Infect. , 56(4):305-311. 
حدوث ال Nocardiosis بين مرضى إصابات الجهاز التنفسي السفلي

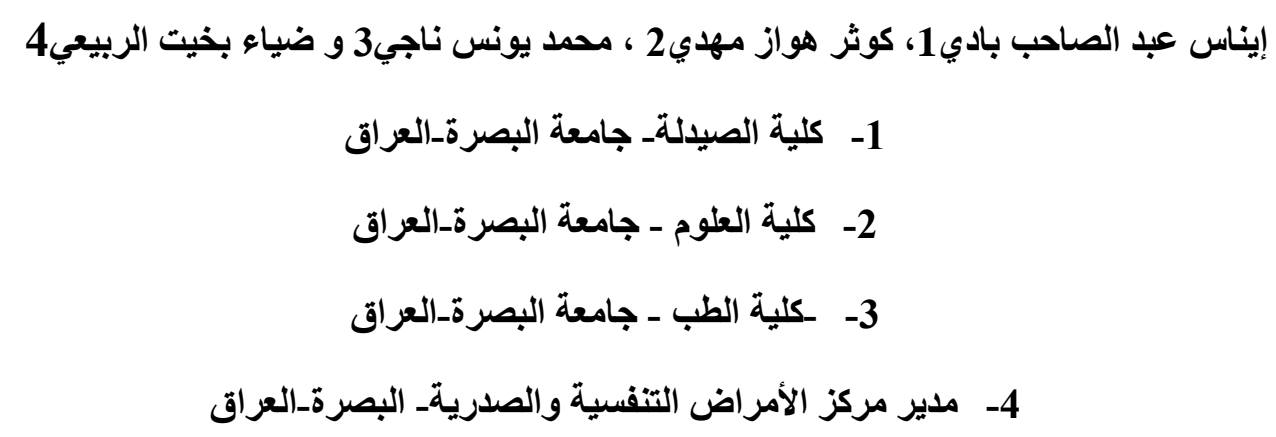

الخلاصة

ثلاثة وتسعون مريضا يعانون من إصابات الجهاز التنفسي السفلي مثل السل الرئوي (44) والتهاب القصبات (49)

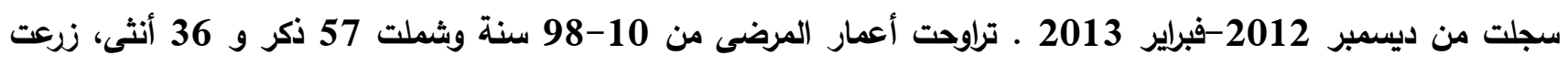

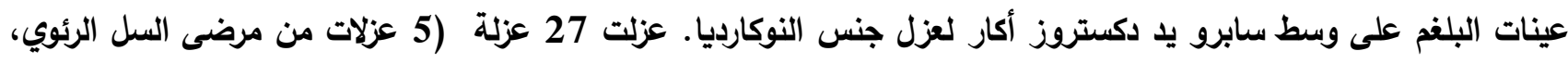

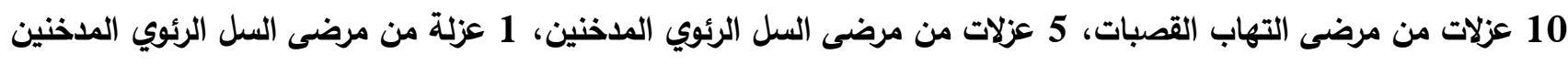

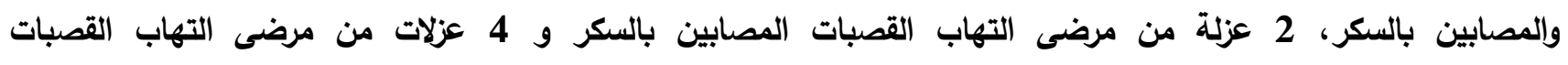

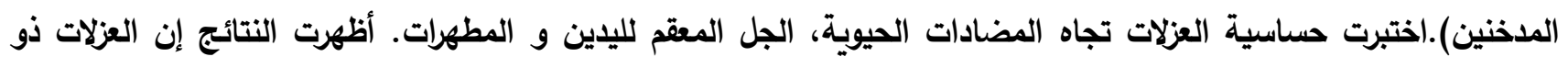

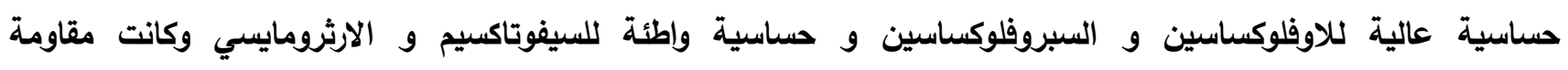

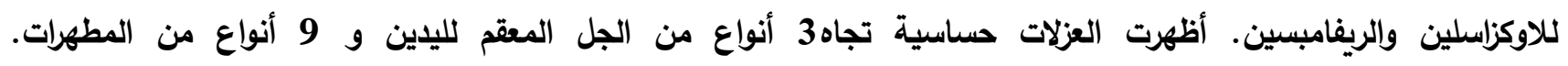

